УДК 338 JEL Q13

Гришин Евгений Викторович аспирант, ФГБОУ ВО «Кубанский государственный аграрный университет имени И. Т. Трубилина», г. Краснодар e-mail: tolmachalex@mail.ru

\section{Grishin Evgenij}

Postgraduate student, Kuban State University named after I. T. Trubilin, Krasnodar e-mail: tolmachalex@mail.ru

\section{ВОПРОСЫ РЕГУЛИРОВАНИЯ РАЗВИТИЯ МАЛОГО АГРАРНОГО ХОЗЯЙСТВОВАНИЯ}

\begin{abstract}
Аннотация. Отмечается, что возможности сегмента малого аграрного хозяйствования используются не в полную силу. Имеют место значительные трудности начала и дальнейшего развития малого производства в вопросах кредитования, страхования рисков, логистики, инновационной модернизации и особенно в сегменте реализачии произведенной продукиии. Приращение научного знания несут уточненную дефиницию малых аграрных форм хозяйствования, а также доработанный автором экономический механизм проиесса регулирования развития субъектов малого хозяйствования. Уделено внимание прочедуре независимого и прозрачного получения субсидий для повышения активности инвестирования в развитие мальх форм хозяйствования.
\end{abstract}

Ключевые слова: малое хозяйствование, дефиниция, господдержка, экономический механизм, прозрачность, развитие.

\section{REGULATORY ISSUES OF THE SMALL AGRICULTURAL FARMING DEVELOPMENT}

\begin{abstract}
It is noted that the opportunities of the small-scale agricultural sector are not being used in full force. There are significant difficulties in starting and further developing small farming in lending, risk insurance, logistics, innovative modernization and especially in the segment of sales of products. The increment of scientific knowledge carries in itself the precise definition of small agrarian forms of farming, as well as the economic mechanism of the process of regulating the development of small-scale economic entities. Particular attention is paid to the procedure of independent and transparent receipt of subsidies for increasing the investment activity in the development of small forms of farming.
\end{abstract}

Keywords: small farming, definition, state support, economic mechanism, transparency, development.

Рыночные трансформации, протекающие в аграрной экономике России определяют вектор развития малого аграрного хозяйствования. В настоящее время малые аграрные формы хозяйствования (далее - МАФХ) занимают значительный сегмент в структуре агропромышленного комплекса: ими производится до 35 \% всей продукции, в том числе мяса - до $45 \%$, молока - до $40 \%$, овощей - до 70 \%. В то же время возможности этого сегмента экономики используют не в полную силу. Здесь имеют место значительные трудности начала и дальнейшего развития своего дела в вопросах кредитования, страхования рисков, логистики, инновационной модернизации и особенно в сегменте реализации произведенной продукции [6; 11].

Протекающие в сельском хозяйстве процессы показывают, что политика ориентации на развитие крупных аграрных формирований в качестве основы всего аграрного производства не совсем оправдывается, поскольку в сельской местности отмечается значительное снижение числа рабочих мест, занятости, растет социальная напряженность. Кроме того, большой аграрный бизнес, несмотря на свои финансовые возможности, мало вкладывается и серьезно сдерживает инновационное развитие всей отрасли. Слабое материально-технологическое обновление агропромышленного производства значительно снижает внешние конкурентные возможности сельского хозяйства в России $[4 ; 8]$.

В то же время потенциал малого аграрного хозяйствования в России особенно в сегменте новаций остается мало востребованным. Такое положение требует проведения детального научного анализа для выявления неиспользованных возможностей дальнейшего развития МАФХ при активном применении инновационного потенциала, развитии инновационной политики, направленной на обеспечение внедрения достижений научно-технического прогресса в отечественном агропромышленном комплексах. В этих условиях весьма востребованы уточнения отдельных теоретических и методологических положений функционирования субъ-

\footnotetext{
(C) Гришин Е.B., 2018 (c) (1)
} 
ектов МАФХ, системные совершенствования инструментов регулирования их развития, процессов импортозамещения и дальнейшей активизации экспортоориентирования.

При наличие большого числа научных исследований в сфере развития малого аграрного хозяйствования проблемы теоретического осмысления, методологического и практического позиционирования, места и роли МАФХ в дальнейшей имплементации региональных программ регулирования развития сферы агропромышленного производства остаются недостаточно изученными, что требует формулирования цели и постановки задач в настоящем исследовании.

Научная гипотеза нашего исследования состоит в научном прогнозе повышения экономической эффективности процесса регулирования развития роста экономического потенциала малого хозяйствования, который позволит повысить конкурентоспособность субъектов этого сегмента аграрного производства, реализовать неиспользованные возможности инновационного развития малых форм сельхозпроизводства.

Целью статьи - разработка методологических основ и направлений практического регулирования развития сектора малого хозяйствования агроэкономики с участием государства. Объектом исследования послужили субъекты малого аграрного хозяйствования экономики Краснодарского края России. Предметом исследования выступили организационные, хозяйственные, управленческие, экономические и социальные отношения, определяющие современный вектор развития малого аграрного хозяйствования.

Научная новизна статьи заключается в уточнении направлений и совершенствовании инструментов регулирования развития субъектов малого аграрного хозяйствования. Наиболее существенны результаты исследования, имеющие элементы новизны, полученные автором:

- уточнено понятие малых аграрных форм хозяйствования (МАФХ);

- доработан экономический механизм процесса регулирования развития субъектов малого хозяйствования.

Дефиниция малых аграрных форм хозяйствования, в отличие от определения «малые формы хозяйствования», уточняется отнесением к ним не только малых сельхозорганизаций, субъектов индивидуального предпринимательства, крестьянско-фермерских хозяйств, личных подсобных хозяйств, но и авторским включением в них домашних, дачных и других производств и их кооперативов при соблюдении критериев по численности работающих, денежной выручке, размеру сельхозугодий, поголовью животных и другим региональным параметрам, при этом работающим не только в производственной отрасли сельского хозяйства, но и других сферах агропромышленного комплекса (далее - АПК), включая переработку и блок розничной реализации сельхозпродукции.

Анализ проведенных исследований показывает, что термин «малые формы хозяйствования» широко используемый в разнообразных нормативных, правовых актах, целевых программах государственной поддержки сельского хозяйства не разъясняет своего содержания, при этом в них нет ответа какиесубъекты следует относить к малому аграрному хозяйствованию [7]. Имеется только косвенное упоминание на структурный состав малых форм хозяйствования в госпрограмме развития с. х. и регулирования рынков сельхозпродукции, где регулирование устойчивости развития малого хозяйствования предлагается осуществлять улучшением доступности к процессу кредитования подсобных производств, крестьянско-фермерских хозяйств и сельскохозяйственных потребительских кооперативов.

Если это упоминание принять в качестве определения понятия малого хозяйствования, то оно включает в себя перечень трех форм отраслевого хозяйствования: личные подсобные хозяйства (далее - ЛПХ), крестьянско-фермерские хозяйства (далее - КФХ) и потребительские сельхозкооперативы. В других федеральных и региональных программах развития сельского хозяйства и малых аграрных производств эта дефиниция имеет более широкое толкование с включением в состав малого хозяйствования, кроме ЛПХ, КФХ и потребительских кооперативов включены микропредприятия (далее - МП) и индивидуальные предприниматели (ИП), осуществляющие сельскохозяйственное производство.

По мнению М. С. Латы, И. А. Папахчян, Р. Н. Лисовской, А. В. Толмачева, А. А. Тубалец и других исследователей, процедуру рассмотрения развития организационно-хозяйственных структур малого хозяйствования следует проводить по этапам их усложнения, начиная от КФХ, индивидуальных аграрных к сельскохозяйственным кооперативам потребления со статусом организационно-правовой формы юридических лиц $[4 ; 5 ; 6 ; 7 ; 8 ; 9]$. Они настаивают, что на этом пути важным критерием классификации исследуемых субъектов 
должны выступить качественные характеристики, обусловленные диверсификацией организационных и правовых форм МАФХ, целевой направленностью производства сельхозпродукции с учетом собственных потребностей, объемов переработки и реализации, с учетом использования собственных или привлеченных со стороны трудовых ресурсов, степенью восприимчивости инновационного развития и другими признаками. Мы разделяем мнение, что использование перечисленных классификационных признаков для классификации субъектов малого хозяйствования оправдан с научных позиций больше в плане теоретического осмысления участия в производстве всех разновидностей МАФХ в качестве субъектов частного предпринимательства.

По автора, основную нагрузку в определении малых аграрных форм хозяйствования должны нести количественные характеристики согласно ФЗ № 209 от 27.11.2017 «О развитии малого и среднего предпринимательства в РФ» [1]. Наша дефиниция MAX, в отличие от определения «малые формы хозяйствования» (к которым обычно относят только участников малых сельхозорганизаций, индивидуальных предпринимателей, КФХ, ЛПХ), предполагает отнесение к ним также домашних, дачных и других производств и их кооперативов при соблюдении критериев по численности работающих, денежной выручке, размерам сельхозугодий, поголовью животных (а при необходимости и других региональных ограничений), которые функционируют не только в сегменте производства сельского хозяйства, но и других сферах АПК, включая переработку и розничный блок сельхозпродукции.

Таким образом, в субъекты малых аграрных форм хозяйствования автор включает не только подсобные хозяйства, субъекты малого индивидуального производства, крестьянские хозяйства, малые сельхозорганизации, потребкооперативы при объемах реализации менее 120 млн руб., с численностью менее 15 чел., собственной или арендуемой земельной площадью менее 1000 га, а также, в отличие от других определений, хозяйства населения, домашние производства, дачные хозяйства. К малому аграрному производству автор относит субъекты достаточно ограниченные числом работающих, размерами производства и объемами реализованной продукции (в стоимостном выражении). Малые субъекты хозяйствования характеризуются большим стремлением к независимости от государства и значительно привязаны к региональному потреблению, они объективно предрасположены к потребительскому кооперированию, но субъективно проявляют большое недоверие к нему [3; 10].

По мнению автора данное определение следует рассматривать применительно не только ко II-й производственной, но и к III-й перерабатывающей и IV-й рыночной сферам агропромышленного комплекса. Всех производителей малых объемов сельскохозяйственной продукции на всех этапах собственного производства, переработки и реализации следует относить к малым формам хозяйствования. Следует понимать, что малые формы, занятые в основном самообеспечением согласно Ф3-№ 112 «О личном подсобном хозяйстве» к бизнесу или предпринимательству сегодня не относятся, хотя они и составляют значительный сегмент малого товарного производства [2].

Важность количественных классификационных признаков малого хозяйствования обусловливается также практикой растущих объемов бюджетных инвестиционных вливаний, направляемых государством на регулирование их развития как важного инструмента управления. Процесс инвестирования государственных финансовых ресурсов на поддержку отраслей сельского хозяйства сопровождается строгими законодательными ограничениями, потому на настоящем этапе так важна правильная классификация границ отнесения производств к малому хозяйствованию с точным указанием количественных и качественных характеристик.

Экономический механизм процесса регулирования развития субъектов малого хозяйствования, в котором основными инструментами выступают внешние административные и экономические возможности предоставления государственной поддержки, дополнен нами включением в него блока активного участия малых сельхозпроизводителей в процедуре независимого и прозрачного получения субсидирования для целей развития производства на условиях частно-государственного долевого финансирования.

Экономический механизм развития субъектов МАФХ рассматривается нами как метод, инструмент регулирования процесса управления изменениями в субъектах МАФХ и понимается нами как совокупность экономических, административных, правовых, других инструментов, которые используются в ходе процессов принятия решений с целью обеспечения устойчивого развития малого хозяйствования, повышения его эффективности и конкурентоспособности, роли в импортозамещении. Схема процесса регулирования развития субъектов малого хозяйствования с участием государства дополнена нами блоком 
участиямалых сельхозпроизводителей в процедуре независимого и прозрачного получения субсидирования для повышения активности инвестирования в развитие производства на условиях частно-государственного долевого финансирования.

Востребованность этого блока практикой объясняется недостаточно прозрачным механизмом государственного субсидирования реализуемого в настоящее время субъективными решениями региональных министерств сельского хозяйства. Мы предлагаем процесс принятия решений о субсидировании строить на основе нормативных регламентов соблюдения уровня софинансирования инвестиционных инициатив с обязательным участием субъектов МАФХ с учетом стадии их развития. Новая заинтересованная сторона принятия решения в лице малых субъектов хозяйствования сможет активно контролировать процесс распределения и предоставления государственных субсидий.

\section{Библиографический список}

1. Федеральный закон № 209 от 24.07.2010 «О развитии малого и среднего предпринимательства в Российской Федерации» (ред. от 03.08.2018) // [Электронный ресурс]. - Режим доступа: Справочная правовая система «Консультант Плюс» (дата обращения: 26.08.2018).

2. Федеральный закон № 112 от 07.07.2003 «О личном подсобном хозяйстве» (принят ГД ФС РФ 21.06.2003) (ред. от 03.08.2018) // [Электронный ресурс]. - Режим доступа: Справочная правовая система «Консультант Плюс» (дата обращения: 26.08.2018).

3. Гришин, Е. В. Прогнозирование емкости рынка по продукции малого хозяйствования / Е. В. Гришин, А. В. Толмачев // Политематический сетевой электронный научный журнал Кубанского государственного аграрного университета. 2016. № 120. - C. 253-264.

4. Лата, М. С. Инновационное развитие малых форм хозяйствования в аграрном секторе экономики :автореф. дис. ... канд. экон. наук :08.00.05 / М. С. Лата. - Волгоград: ВГАУ, 2018. - 24 с.

5. Папахчян, И. А. Государственное регулирование развития малого аграрного хозяйствования / И. А. Папахчян, А. А. Тубалец, Р. Н. Лисовская [и др.]. Под общей редакцией А. В. Толмачева. - Краснодар : КубГАУ, 2016. - 161 с.

6. Сельское хозяйство Краснодарского края. Статистический сборник. - Краснодар: Краснодарстат, 2017. - 234 с.

7. Толмачев, А. В. Развитие региональной аграрной экономики и роль малого хозяйствования / А. В. Толмачев, И. А. Папахчян, Р. Н. Лисовская // Политематический сетевой электронный научный журнал Кубанского государственного аграрного университета. 2015. - № 111.- С. 776-792.

8. Тубалец, А. А. Особенности развития и регулирования субъектов малых форм хозяйствования в АПК / А. А. Тубалец, Р. Н. Лисовская // Политематический сетевой электронный научный журнал Кубанского государственного аграрного университета. 2012. - № 84. - С. 703-717.

9. Тубалец, А. А. Ретроспектива развития и регулирования малых форм производства / А. А. Тубалец, Р. Н. Лисовская, А. В. Толмачев // Политематический сетевой электронный научный журнал Кубанского государственного аграрного университета. 2015. - № 108. - С. 654-668.

10. Экономика регионов: тенденции развития / И. Л. Авдеева, И. Г. Акчурина, Е. С. Алехина [и др.]. - Воронеж: ВГПУ, 2013. $-329 \mathrm{c}$.

11. Российские реформы в цифрах и фактах. [Электронный ресурс]. - Режим доступа: http://russianpulse.ru/ (дата обращения 27.08.2018).

\section{References}

1. Federal'nyj zakon № 209 ot 24.07.2010 «O razvitii malogo i srednego predprinimatel'stva v Rossijskoj Federacii» [On the development of small and medium-sized businesses in the Russian Federation]. Available at: System of «Consultant Plus» (accessed 26.08.2018).

2. Federal'nyj zakon № 112 ot 07.07.2003 «O lichnom podsobnom khozyajstve» [About personal subsidiary farm] (prinyat GD FS RF 21.06.2003). Available at: System of «Consultant Plus» (accessed 26.08.2018).

3. Grishin E. V., Tolmachev A. V. Prognozirovanie emkosti rynka po produkcii malogo khozyajstvovaniya [Forecasting of market capacity for the products of the small farming] // Politematicheskij setevoj elektronnyj nauchnyj zhurnal Kubanskogo gosudarstvennogo agrarnogo universiteta, 2016, I. 120, pp. 253-264. 
4. Lata M. S. Innovacionnoe razvitie malykh form hozyajstvovaniya v agrarnom sektore ekonomiki [Innovative development of small farming in the agricultural sector]: avtoref. dis. ... kand. ekon. nauk :08.00.05. Volgograd: VGAU, 2018, p. 24.

5. Papakhchyan I. A., Tubalec A. A., Lisovskaya R. N. [et.al.]. Edited by Tolmacheva A. V. Gosudarstvennoe regulirovanie razvitiya malogo agrarnogo khozyajstvovaniya [State regulation of small agricultural business development]. Krasnodar: KubGAU, 2016, p. 161.

6. Sel'skoe khozyajstvo Krasnodarskogo kraya. Statisticheskij sbornik [Agriculture of Krasnodar region. Statistical compendium]. Krasnodar: Krasnodarstat, 2017, p. 234.

7. Tolmachev A. V., Papakhchyan I. A., Lisovskaya R. N. Razvitie regional'noj agrarnoj ekonomiki i rol' malogo khozyajstvovaniya [Development of regional agricultural economy and the role of small business]. Politematicheskij setevoj elek-tronnyj nauchnyj zhurnal Kubanskogo gosudarstvennogo agrarnogouniversiteta, 2015, I. 111, pp. 776-792.

8. Tubalec A. A., Lisovskaya R. N. Osobennosti razvitiya i regulirovaniya sub'ektov malykh form khozyajstvovaniya v APK [Features of development and regulation of subjects of small forms of management in agriculture]. Politematicheskij setevoj elektronnyj nauchnyj zhurnal Kubanskogo gosudarstvennogo agrarnogo universiteta, 2012, I. 84, pp. 703-717.

9. Tubalec A. A., Lisovskaya R. N., Tolmachev A. V. Retrospektiva razvitiya i regulirovaniya malykh form proizvodstva [Retrospective of development and regulation of small forms of production]. Politematicheskij setevoj elektronnyj nauchnyj zhurnal Kubanskogogosudarstvennogo agrarnogo universiteta, 2015, I. 108, pp. 654-668.

10. Avdeeva I. L., Akchurina I. G., Alekhina E. S. [et.al.]. Ekonomika regionov: tendencii razvitiya [Regional economy: development trends], Voronezh: VGPU, 2013, p. 329.

11. Rossijskie reformy v cifrakh i faktakh [Russian reforms in facts and figures]. Available at: http://russianpulse.ru/ (accessed 20.05.2018). 